\title{
INTEGRATING THE OBJECTIVES OF SUSTAINABLE DEVELOPMENT INTO TEACHING
}

\author{
Ricardo Chalmeta, Manuel Mollar, Guillermo Peris \\ Grupo de Integración y Re-ingeniería de Sistemas. Dept. Lenguajes y Sistemas \\ Informáticos. Universitat Jaume I (SPAIN)
}

\begin{abstract}
The approval in September 2015 of the 2030 Agenda and the sustainable development goals (SDG) by the General Assembly of the United Nations will change the work paradigm in countries, companies, and citizens. The Sustainable Development Goals are the blueprint to achieve a better and more sustainable future for all. They address the global challenges we face, including those related to poverty, inequality, climate change, environmental degradation, peace and justice.

Universities cannot be excluded from these changes. Thus, the agreement signed among different Spanish universities and the Department of Transparency, Social Responsibility, Participation and Cooperation of the Generalitat Valenciana (Spain) promotes greater knowledge of the 2030 Agenda and the SDGs by the university community.

This paper describes the project carried out by the educational innovation group of the Jaume I University of Castellón to integrate the objectives of sustainable development into teaching. Paper shows the general and specific objectives of the project, the work plan developed, the indicators used to measure the success of the project, and the results achieved. The benefits of the project are summarized in (1) the identification of the necessary skills for sustainability both in teachers and students, (2) the evaluation and comparison of teachers and students' sustainability and SDG knowledge through a questionnaire, and (3) the re-design of the curriculum of different subjects.
\end{abstract}

Keywords: sustainable development goals, 2030 Agenda, learning experiences, curriculum design.

\section{INTRODUCION}

The adoption by the United Nations General Assembly of the 2030 Agenda and the Sustainable Development Goals (SDGs) [1] in September 2015 (table 1) changes the paradigm of the work that states, citizens and organizations, have to develop in the future $[2,3,4,5]$.

\section{Table 1. The 17 Sustainable Development Goals}

1. End of poverty. Ending poverty in all its forms around the world

2. Zero hunger. Ending hunger, achieving food security and improving nutrition and promoting sustainable agriculture

3. Health and well-being. Ensuring a healthy life and promoting well-being for all at all ages

4. Quality education. Ensuring inclusive, equitable and quality education and promoting lifelong learning opportunities for all

5. Gender equality. Achieving gender equality and empowering all women and girls

6. Clean water and sanitation. Ensuring the availability of water and its sustainable management and sanitation for all

7. Affordable, non-polluting energy. Ensuring access to affordable, safe, sustainable and moderate energy for all

8. Decent work and economic growth. Promoting sustained, inclusive and sustainable economic growth, full and productive employment and decent lower employment for all
10. Reduction of inequalities. Reducing inequality in and between countries

11. Sustainable cities and communities. Making cities and human settlements inclusive, safe, resilient and sustainable

12. Responsible production and consumption. Ensuring sustainable consumption and production modalities

13. Climate action. Take urgent action to combat climate change

14. Underwater life. Sustainably conserve and use oceans, seas and marine resources for sustainable development

15. Life of terrestrial ecosystems. Protect; restore and promote the sustainable use of terrestrial ecosystems, sustainably manage forests, fight with/to desertification, stop and reverse land degradation and stop biodiversity loss

16. Peace. justice and strong institutions. Promote societies, just, peaceful and inclusive for sustainable development: providing all people with access to (just and developing effective, accountable and inclusive institutions at all levels)

17. Partnerships to achieve goals. Strengthen the means of implementation and revitalize the Global Partnership for Sustainable Development 
9. Industry. innovation and infrastructure.

Consuming resilient infrastructures, promoting

inclusive and sustainable industrialization, and

fostering innovation

Universities cannot be on the sidelines of these changes [6,7]. Thus, the Agreement signed between universities and the Ministry of Transparency, Social Responsibility, Participation and Cooperation of the Generalitat Valenciana (Spain) promotes the greater knowledge of the Agenda and the SDGs by the university community.

For this reason, the teaching innovation group (GIE) of the Universitat Jaume I de Castellón has carried out a project to integrate the objectives of sustainable development in the teaching of three subjects taught in four degrees of the Universitat Jaume I de Castellón, and in three different centers of the UJI. Below is the description of this innovation project and the results achieved

\section{PROJECT OBJECTIVES AND WORK PLAN}

\subsection{Objectives}

The objective of this innovation project is to integrate the objectives of sustainable development into the teaching of three subjects of the UJl, improving the skills for the sustainability of teachers and students, while identifying the necessary changes in the teaching guides in order to introduce in their teaching this paradigm of change through sustainability. In order to achieve this general objective, the following specific objectives are set:

- Training the components of the GIE in the definition and evolution of the concept of sustainability/sustainable development, in the 2030 Agenda and in the SDGs, as well as to increase awareness of its importance.

- Analyze the content of the 2030 Agenda with the aim of identifying the role of the University in the face of the overall challenge of achieving the SDGs.

- Identify the necessary competences of the teachers in relation to sustainability.

- Carry out exploratory and cooperative work to determine which sustainability competencies [8, 9] are held by GIE members and in which they need training, as well as the students of the subjects PE0918-Computer Tools for Communicators (Informatics) of the degree of Journalism, of the subject El1034-Computer Security of the degrees Computer Engineering and Computational Mathematics, and of the subject GA1220-Information Systems for economic management of the degree of Management of the Public Administration.

- Identification of the means available to acquire such competences.

- Concrete the theoretical ideas worked and apply them to begin to transform teaching by questioning what aspects of the three sustainability dimensions (environmental, social and economic) are already included in the teaching guides and which should be included.

- Design of more sustainable common future scenarios that can be achieved from the teaching of GIE members. For this purpose, the contents, teaching methodology, values, etc. will be analyzed and changes will be proposed in the teaching guides of the subjects PE0918, El1034, and GA1220.

\subsection{Work Plan}

To achieve the proposed objectives, the following work plan was established:

Activity 1: Review of Sustainability and Teaching-Related Literature, and 2030 Agenda Analysis

Activity 2: Identification of skills necessary for sustainability, and assessment and comparison of teachers and students knowledge and skills through a questionnaire (see table 2), and implement tools for knowledge management $[10,11]$. The questionnaire was built using [12] proposals.

Activity 3: Teacher training deficiencies identified 
Activity 4: Re-Design of the teaching guides of the subjects PE0918-Computer Tools for Communicators (Informatics) of the degree of Journalism, El1034-Computer Security of the Degrees Computer Engineering and Computational Mathematics, and GA1220Information Systems for Economic Management of the degree of Management of the Public Administration

The following figure shows the duration of every activity.

\begin{tabular}{|l|l|l|}
\hline & First Semester & Second Semester \\
\hline Activity 1: Literature Review and State of the art analysis & & \\
\hline Activity 2: Identification of skills and assessment & & \\
\hline Activity 3: Teacher training in the deficiencies identified & \\
\hline Activity 4: Re-Design of the teaching guides of the subjects & \\
\hline
\end{tabular}

Figure 1. Work Plan duration

\section{FINDINGS}

The results achieved are summarized in:

- Evaluate and compare the skills for the sustainability of teachers and students of the three subjects mentioned above, which are taught in three different centers of the Universitat Jaume I: the Faculty of Human and Social Sciences, the Faculty of Legal and Economic Sciences, and the Higher School of Technology and Experimental Sciences.

- Improving sustainability skills in both the students of the three subjects and the three GIE teachers who teach them, as well as society in general by proposing more sustainable common future scenarios

- The improvement of the teaching guides of three subjects, by incorporating in them sustainability criteria, which can also be used as example cases for the re-design of the other teaching guides of the UJI.

The quantitative indicators that allowed the action to be evaluated are:

- Results of the questionnaire to identify the current skills of the teachers in sustainability and the students of the three subjects. Descriptive statistics were used to generate comparisons between the students of the different subjects, which are taught in different degrees and centers.

- Teacher training actions to improve their sustainability skills

- Proposal for the improvements to be implemented in the teaching guide of the three subjects

Table 2. Questionarie questions

1. Have you heard of the United Nations Sustainable Development Goals (SDGs) and the 2030 Agenda during your academic life?

2. In what area have you heard of the SDGs?

3. How knowledgeed do you have about the Sustainable Development Goals:

4. Do you know if your university has done any training, workshops or activities on Sustainable Development Goals:

5. Have you participated in any activities on the Sustainable Development Goals?

6. Would you like to know what is happening in the world and have more knowledge and resources on the Sustainable Development Goals and the 2030 Agenda, which is the agreement of 193 United Nations member countries for the future of humanity and the planet?

7. How would you like to receive this information, knowledge and actions?

8. Would you like to be taught at the University how from your (future) profession you could help create a more sustainable world?

9. In case from university offer complementary shares to know the SDGs, which ones do you find most attractive? 
10. Do you know what Global Citizenship Education is?

11. Have you received any talks or participated in any Global Citizenship Education activity with any organization or at the University?

12. What issues related to the SDGs are of concern to you?

13. Do you consider yourself a person who fights social injustices?

14. Do you think it is important to change your values, behaviors, and habits so that Humanity and the Planet have a future?

\section{CONCLUSIONS}

Compliance with the SDGs is critical to ensuring the well-being of society and future generations. To achieve them, education is key, because in addition to being one of the sustainable goals in itself, it is one of the main tools to raise awareness and engage citizens. Therefore, it is necessary to review the extent to which the SDGs are currently being worked on in the different degrees of universities, identifying strengths and weaknesses, as well as proposing improvements to enable their action towards a Comprehensive Sustainable Development Education.

The innovation project shown here can be used as a case study for the implementation of improvements in the teaching guides of the rest of the subjects of the Universitat Jaume I, as well as other universities.

\section{REFERENCES}

[1] Naciones Unidas (2015). Agenda 2030 para el Desarrollo Sostenible. París. 30/11/2019, de ONU https://undocs.org/es/A/RES/70/1

[2] Leon-Soriano, R.; Jesus Munoz-Torres, M.; Chalmeta-Rosalen, R. (2010) Methodology for sustainability strategic planning and management. Industrial Management \& Data Systems 110(1-2) 249-268

[3] Gomez, L. M.; Chalmeta, R. Corporate responsibility in U.S. corporate websites: A pilot study. (2011) Public Relations Review 37(1) 93-95

[4] Chalmeta, R.; Palomero, S (2011). Methodological proposal for business sustainability management by means of the Balanced Scorecard. Journal Of The Operational Research Society 62 (7) 1344-1356

[5] Unesco (1992). Conferencia de las Naciones Unidas sobre el Desarrollo Sostenible. Río de Janeiro, 3 al 14 de junio. París 30/11/2019, de UNESCO. http://www.unesco.org/education/nfsunesco/pdf/RIO_S.PDF

[6] Rabiatul, A (2012). Teachers' Knowledge of Education for Sustainable Development. 29/11/2019 de University of Malasya https://www.researchgate.net/publication/263011209_ Teachers'_Knowledge_of_Education_for_Sustainable_Development

[7] Unesco (2017). Educación para los Objetivos de Desarrollo Sostenible; Objetivos de aprendizaje. París. 30/11/2019, de UNESCO.

https://unesdoc.unesco.org/ark:/48223/pf0000252423

[8] Cortado, F.J.; Chalmeta, R. (2016). Use of social networks as a CSR communication tool. Cogent Business \& Management $3 n^{\circ}$ paper 1187783 Fecha de publicación: 2016

[9] Anyolo, E. (2018). Implementing Education for Sustainable Development in Namibia: School Teachersí Perceptions and Teaching Practices. 29/11/2019 de University of Namibia https://www.researchgate.net/publication/326039301_Implementing_Education_for_Sustainable _Development_in_Namibia_School_Teachers'_Perceptions_and_Teaching_Practices

[10] Orenga-Rogla, S., Chalmeta, R., (2019). Methodology for the Implementation of Knowledge Management Systems 2.0: A Case Study in an Oil and Gas Company. Business \& Information Systems Engineering, 61(2) 195-213

[11] Orenga-Rogla, S., Chalmeta, R., (2019). Framework for Implementing a Big Data Ecosystem in Organizations. Communications of the ACM, 62(1) 58-65 
[12] Open Course Ware (2017). Tema 2. Métodos de valoración. Cuestionarios 28/01/2020, de Universidad de Cantabria https://ocw.unican.es $/ \mathrm{mod} / \mathrm{page} / \mathrm{view} . \mathrm{php}$ ?id=498\#2 